\title{
Caddo Ceramic Vessels from the Fred Yarbrough Site (41VN6) in the Upper Sabine River Basin, Van Zandt County, Texas
}

Timothy K. Perttula

Heritage Research Center, Stephen F. Austin State University

Follow this and additional works at: https://scholarworks.sfasu.edu/ita

Part of the American Material Culture Commons, Archaeological Anthropology Commons, Environmental Studies Commons, Other American Studies Commons, Other Arts and Humanities Commons, Other History of Art, Architecture, and Archaeology Commons, and the United States History Commons

Tell us how this article helped you.

This Article is brought to you for free and open access by the Center for Regional Heritage Research at SFA ScholarWorks. It has been accepted for inclusion in Index of Texas Archaeology: Open Access Gray Literature from the Lone Star State by an authorized editor of SFA ScholarWorks. For more information, please contact cdsscholarworks@sfasu.edu. 


\section{Caddo Ceramic Vessels from the Fred Yarbrough Site (41VN6) in the Upper Sabine River Basin, Van Zandt County, Texas}

\section{Creative Commons License}

\section{(c) (1) \&}

This work is licensed under a Creative Commons Attribution-NonCommercial 4.0 International License 


\section{Caddo Ceramic Vessels from the Fred Yarbrough Site (41VN6) in the Upper Sabine River Basin, Van Zandt County, Texas}

Timothy K. Perttula

\section{INTRODUCTION}

Excavations in 1940 by the Works Progress Administration (WPA) at the Fred Yarbrough site (41VN6) in the upper Sabine River basin (Figure 1) recovered a number of ceramic vessels from Area B of the site (Johnson 1962:225; see also Wilson 1950). Johnson (1962:226-230 and Figure 22a-g) provided an initial description of the vessels as well as drawings of a number of the reconstructed vessels. In this article, I reexamine the nine vessels from the Fred Yarbrough site held in the collections of the Texas Archeological Research Laboratory at the University of Texas at Austin (TARL), employing the vessel documentation protocol used in recent years to document ancestral Caddo vessels from sites in East Texas, and I also provide photographs of each of the vessels.

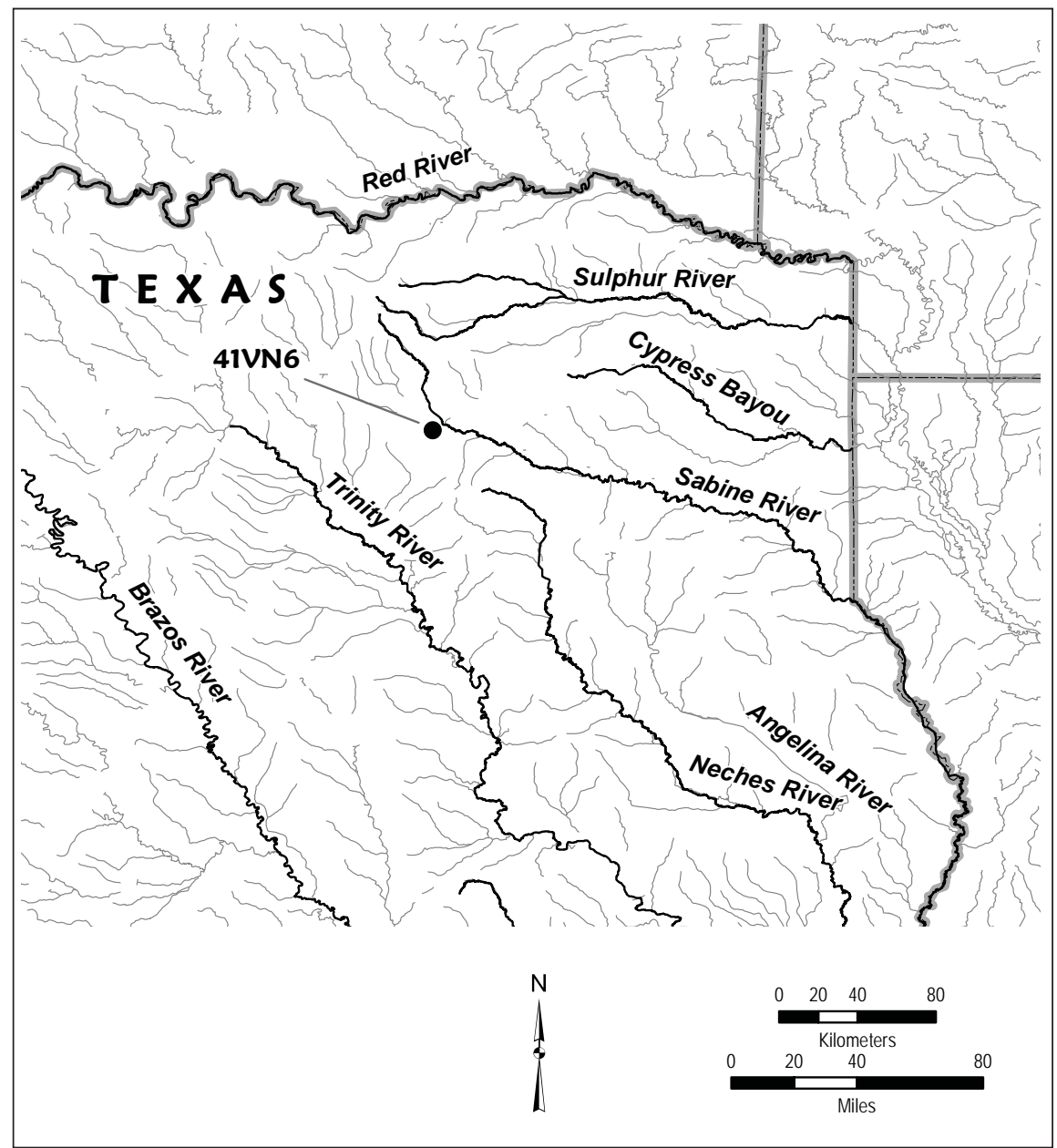

Figure 1. The location of the Fred Yarbrough site in the upper Sabine River basin in East Texas. 


\section{Archaeological Context}

The Fred Yarbrough site is a multi-component Paleoindian, Archaic, Woodland, and ancestral Caddo occupation in the Sabine River floodplain in the upper Sabine River basin (Johnson 1962:155). The ceramic vessels described and documented herein are from Area B of the site, described by Johnson (1962:224-225) as follows:

This consisted of a small area, approximately 20 feet in diameter, of dark humus-stained midden soil containing many potsherds and bone scraps...it was a small habitation area of one, or at the most, two houses.

In addition to the recovery of 612 ceramic vessel sherds from Area B, a total of nine ceramic vessels were reconstructed by the WPA laboratory. Johnson (1962:225) noted that this "relatively large number of pots is somewhat surprising considering the small amount of sherds, and leads one to wonder whether they represent furniture from graves or other features which could have been destroyed by repeated agricultural cultivation of a recent date." The provenience information at TARL associated with the vessels indicates that six of the vessels are from a "burned area" or "burned area on house site," suggesting the vessels may have been in situ inside an ancestral Caddo house when it was burned down, thus limiting their spatial dispersal.

\section{Caddo Ceramic Vessels}

The nine vessels from the Fred Yarbrough site include two jars, two carinated bowls, three bowls, and two bottles. Only one of the carinated bowls, one of the bowls, one of the bottles, and one of the jars are decorated (44 percent of the vessels in the site assemblage); only one of the vessels (11 percent) has a slip on its exterior surface.

SITE NAME OR SITE NUMBER: Fred Yarbrough

VESSEL NO.: 1, 6-154-193; in burned area on house site

VESSEL FORM: Bottle

NON-PLASTICS AND PASTE: grog and bone

RIM AND LIP FORM: N/A

CORE COLOR: $\mathrm{G}$ (fired in a reducing environment and cooled in the open air)

INTERIOR SURFACE COLOR: brown; fire clouds on the body

EXTERIOR SURFACE COLOR: dark red; fire clouds on the body

WALL THICKNESS (IN MM): body, $6.3 \mathrm{~mm}$

INTERIOR SURFACE TREATMENT: none 
EXTERIOR SURFACE TREATMENT: burnished

HEIGHT (IN CM): N/A

ORIFICE DIAMETER (IN CM): N/A

DIAMETER AT BOTTOM OF RIM OR NECK (IN CM): N/A; maximum body diameter is $14.6 \mathrm{~cm}$

BASE DIAMETER (IN CM) AND SHAPE OF BASE: 7.1; circular and rounded

ESTIMATED VOLUME (IN LITERS): N/A

DECORATION (INCLUDING MOTIF AND ELEMENTS WHEN APPARENT): There is a poorly preserved red slip on the exterior vessel surface (Figure 2).

PIGMENT USE AND LOCATION ON VESSEL: none

TYPE AND VARIETY (IF KNOWN): Sanders Slipped (Perttula et al. 2016)

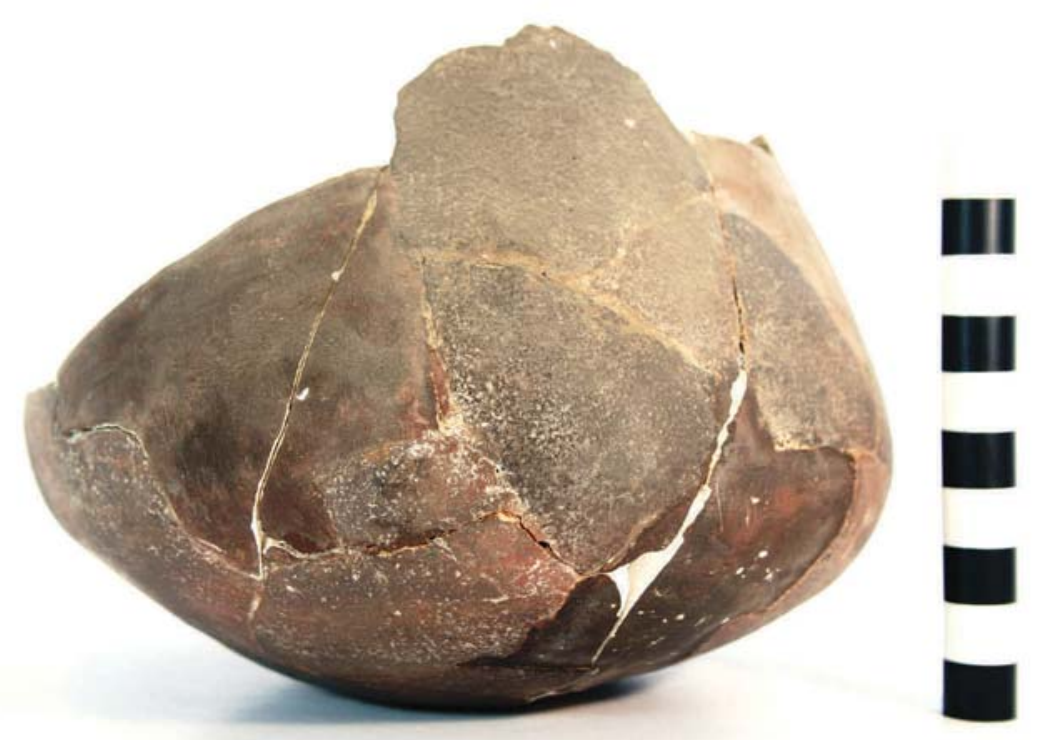

Figure 2. Sanders Slipped bottle section from the Fred Yarbrough site. 
SITE NAME OR SITE NUMBER: Fred Yarbrough

VESSEL NO.: 2, 6-154-286, burned area on house site

VESSEL FORM: Bowl

NON-PLASTICS AND PASTE: grog and bone

RIM AND LIP FORM: Direct rim and rounded lip

CORE COLOR: A (fired and cooled in an oxidizing environment)

INTERIOR SURFACE COLOR: reddish-brown

EXTERIORSURFACECOLOR:

yellowish-brown; fire clouds on the rim and body

WALL THICKNESS (IN MM): rim, $6.3 \mathrm{~mm}$

INTERIOR SURFACE

TREATMENT: none

EXTERIOR SURFACE

TREATMENT: smoothed

HEIGHT (IN CM): 8.9

ORIFICE DIAMETER (IN

$\mathrm{CM}): 11.7$

DIAMETER AT BOTTOM OF RIM OR NECK (IN CM): N/A

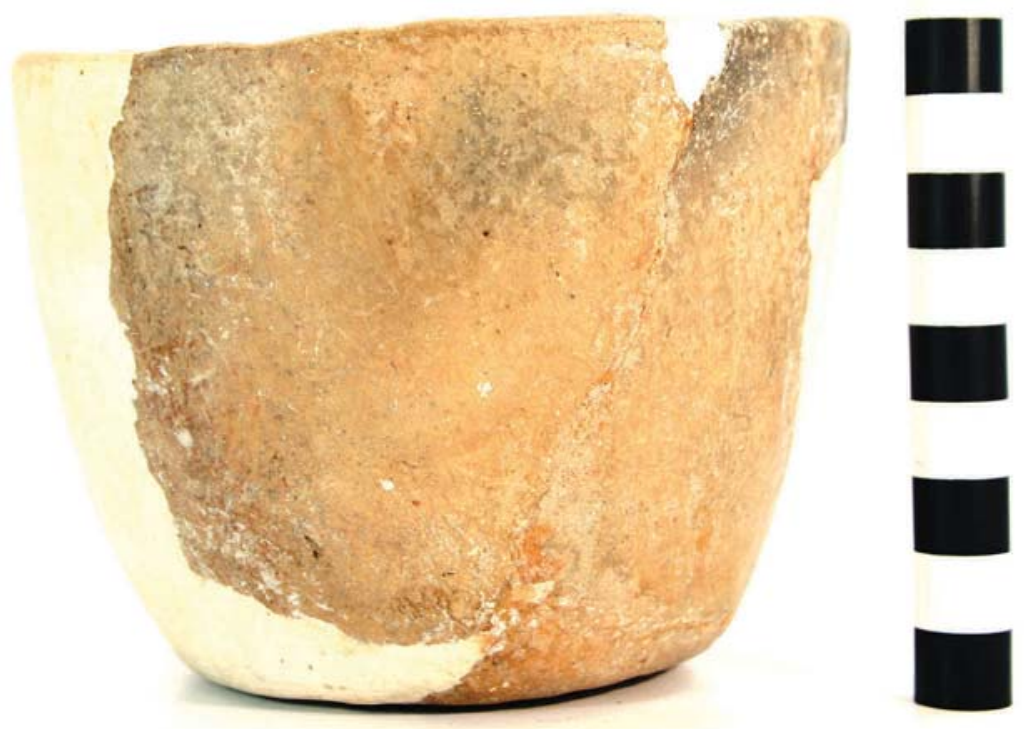

Figure 3. Plain bowl from the Fred Yarbrough site.

BASE DIAMETER (IN CM) AND

SHAPE OF BASE: 7.2; circular and flat

ESTIMATED VOLUME (IN LITERS): 0.4

DECORATION (INCLUDING MOTIF AND ELEMENTS WHEN APPARENT): Plain (Figure 3)

PIGMENT USE AND LOCATION ON VESSEL: none

TYPE AND VARIETY (IF KNOWN): Unidentified plain ware 
SITE NAME OR SITE NUMBER: Fred Yarbrough

VESSEL NO.: 3, 6-154-287

VESSEL FORM: Carinated bowl

NON-PLASTICS AND PASTE: grog

RIM AND LIP FORM: Direct rim and rounded lip

CORE COLOR: F (fired in a reducing environment and cooled in the open air)

INTERIOR SURFACE COLOR: dark reddish-brown; fire clouds on the rim, body, and base

EXTERIOR SURFACE COLOR: reddish-brown; fire clouds on the rim, body, and base

WALL THICKNESS

(IN MM): rim, $4.1 \mathrm{~mm}$

INTERIOR SURFACE

TREATMENT: smoothed

EXTERIOR SURFACE

TREATMENT: burnished on the

lower body; smoothed

HEIGHT (IN CM): 5.8

ORIFICE DIAMETER

(IN CM): 12.3

DIAMETER AT BOTTOM OF

RIM OR NECK (IN CM): 12.4

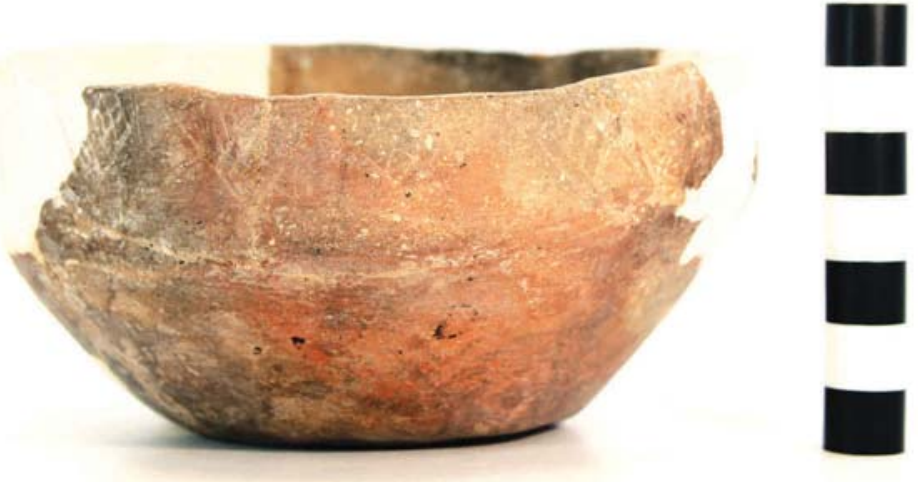

Figure 4. Sanders Engraved carinated bowl from the Fred Yarbrough site.

BASE DIAMETER (IN CM)

AND SHAPE OF BASE: 7.0;

circular and flat

ESTIMATED VOLUME (IN LITERS): 0.4

DECORATION (INCLUDING MOTIF AND ELEMENTS WHEN APPARENT): The rim panel has a series of 18 engraved pendant triangles whose apexes point towards the vessel carination and almost reach the carination; the rim panel is only $2.5 \mathrm{~cm}$ in height. Each of the engraved pendant triangles is filled with cross-hatched engraved lines (Figure 4).

PIGMENT USE AND LOCATION ON VESSEL: none

TYPE AND VARIETY (IF KNOWN): Sanders Engraved 
SITE NAME OR SITE NUMBER: Fred Yarbrough

VESSEL NO.: 4, 6-154-288, burned area

VESSEL FORM: Bowl

NON-PLASTICS AND PASTE: grog and bone

RIM AND LIP FORM: Direct rim and flat lip

CORE COLOR: B (fired and cooled in a reducing environment)

INTERIOR SURFACE COLOR: dark grayish-brown

EXTERIOR SURFACE COLOR: very dark grayish-brown

WALL THICKNESS (IN MM): rim, $5.2 \mathrm{~mm}$

INTERIOR SURFACE TREATMENT: none

EXTERIOR SURFACE TREATMENT: smoothed

HEIGHT (IN CM): 4.4

ORIFICE DIAMETER (IN CM): 14.3

DIAMETER AT BOTTOM OF RIM OR NECK (IN CM): N/A

BASE DIAMETER (IN CM) AND SHAPE OF BASE: 6.4; circular and flat

ESTIMATED VOLUME (IN LITERS): 0.25

DECORATION (INCLUDING MOTIF AND ELEMENTS WHEN APPARENT): Plain (Figure 5)

PIGMENT USE AND LOCATION ON VESSEL: none

TYPE AND VARIETY (IF KNOWN): Unidentified plain ware

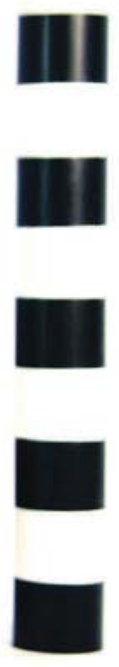

Figure 5. Plain bowl from the Fred Yarbrough site. 
SITE NAME OR SITE NUMBER: Fred Yarbrough

VESSEL NO.: 5, 6-154-289, burned area on house site

VESSEL FORM: Carinated bowl

NON-PLASTICS AND PASTE: grog, bone, and hematite

RIM AND LIP FORM: Direct rim and rounded lip

CORE COLOR: A (fired and cooled in an oxidizing environment)

INTERIOR SURFACE COLOR: reddish-brown; fire clouds on the rim

EXTERIOR SURFACE COLOR: reddish-brown; fire clouds on the rim and body

WALL THICKNESS (IN MM): rim, 6.9 mm

INTERIOR SURFACE TREATMENT: smoothed

EXTERIOR SURFACE TREATMENT: burnished

HEIGHT (IN CM): 8.5

ORIFICE DIAMETER (IN CM): 19.1

DIAMETER AT BOTTOM OF RIM OR NECK (IN CM): 19.0

BASE DIAMETER (IN CM) AND SHAPE OF BASE: 7.6; circular and flat

ESTIMATED VOLUME (IN LITERS): 1.0

DECORATION (INCLUDING MOTIF AND ELEMENTS WHEN APPARENT): Plain (Figure 6)

PIGMENT USE AND LOCATION ON VESSEL: none

TYPE AND VARIETY (IF KNOWN): Unidentified plain ware

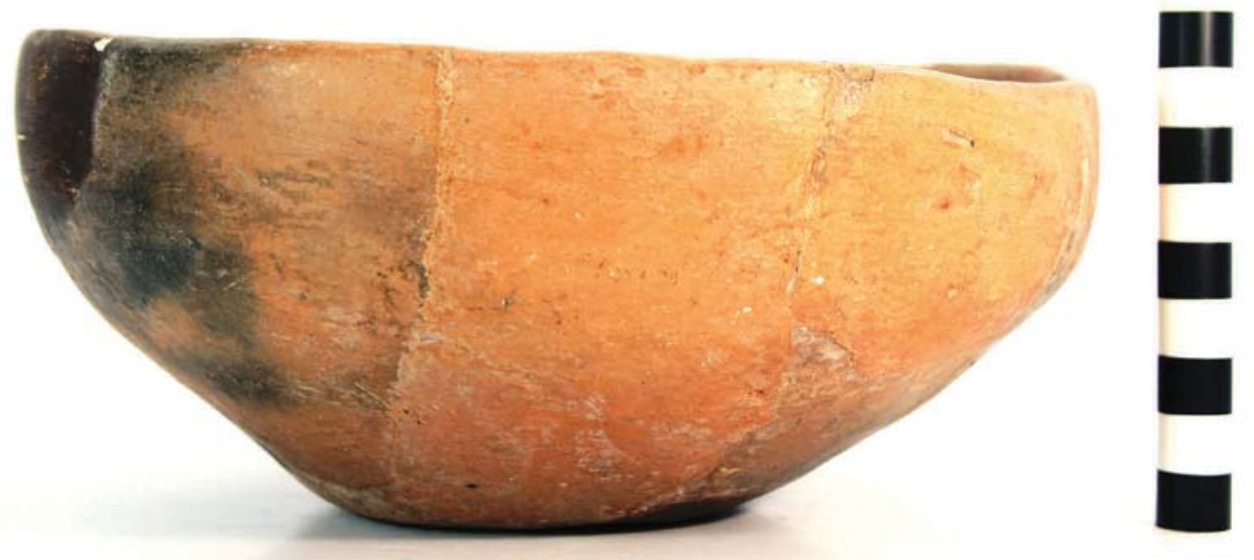

Figure 6. Plain carinated bowl from the Fred Yarbrough site. 
SITE NAME OR SITE NUMBER: Fred Yarbrough

VESSEL NO.: 6, 6-154-290

VESSEL FORM: grog

NON-PLASTICS AND PASTE: Bottle

RIM AND LIP FORM: Direct rim and flat lip

CORE COLOR: G (fired in a reducing environment and cooled in the open air)

INTERIOR SURFACE COLOR: very dark grayish-brown

EXTERIOR SURFACE COLOR: dark yellowish-brown; fire clouds on the rim, body, and base

WALL THICKNESS (IN MM): rim, $5.9 \mathrm{~mm}$

INTERIOR SURFACE TREATMENT: none

EXTERIOR SURFACE TREATMENT: smoothed

HEIGHT (IN CM): 27.0

ORIFICE DIAMETER (IN CM): 4.0

DIAMETER AT BOTTOM OF RIM OR NECK (IN CM): 5.4; maximum body diameter is $15.0 \mathrm{~cm}$

BASE DIAMETER (IN CM) AND

SHAPE OF BASE: 7.6; circular and flat

ESTIMATED VOLUME

(IN LITERS): 0.8

DECORATION (INCLUDING MOTIF AND ELEMENTS WHEN APPARENT): Plain (Figure 7)

PIGMENT USE AND LOCATION ON VESSEL: none

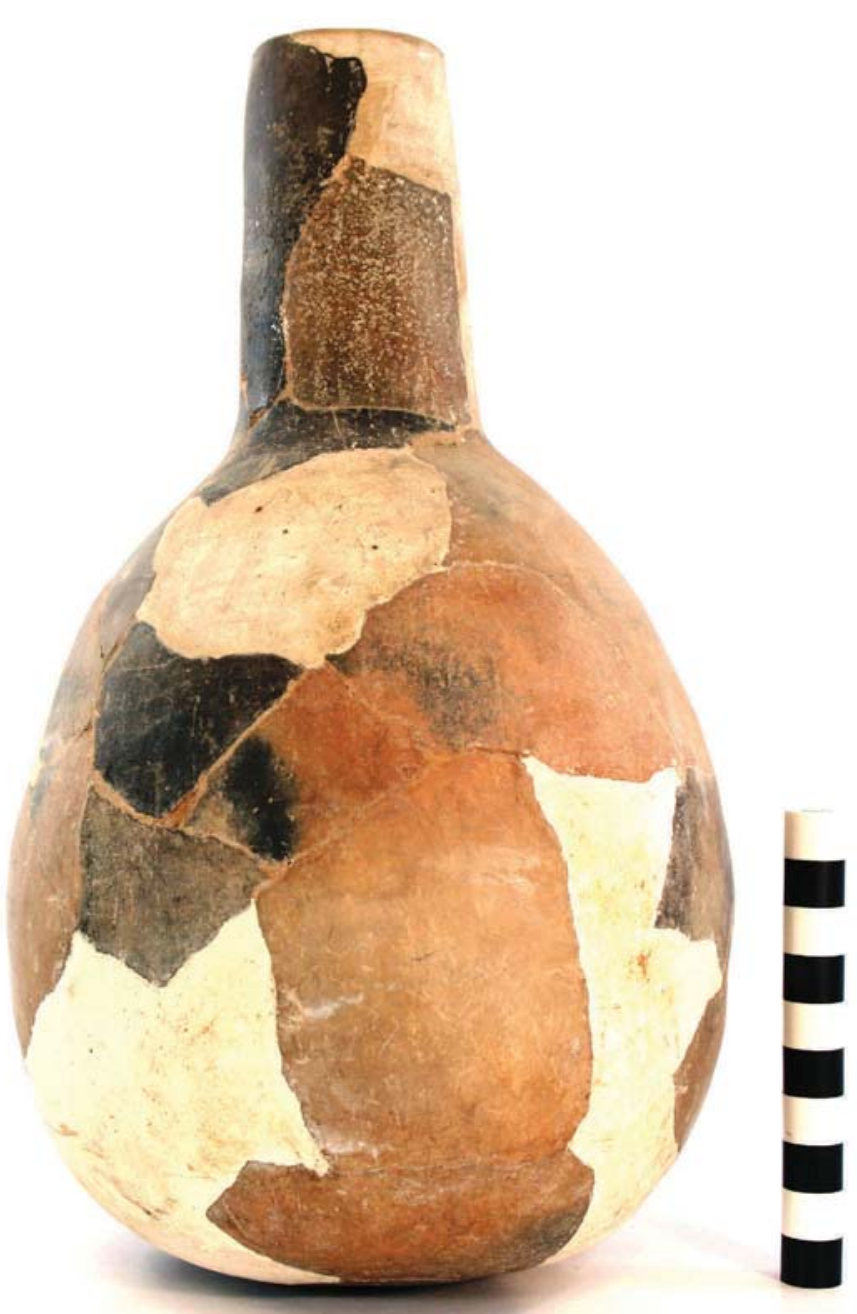

Figure 7. Plain bottle from the Fred Yarbrough site.

TYPE AND VARIETY (IF KNOWN): Unidentified plain ware 
SITE NAME OR SITE NUMBER: Fred Yarbrough

VESSEL NO.: 7, 6-154-291, burned area

VESSEL FORM: Jar or small deep bowl

NON-PLASTICS AND PASTE: grog

RIM AND LIP FORM: Direct rim and rounded lip

CORE COLOR: F (fired in a reducing environment and cooled in the open air)

INTERIOR SURFACE COLOR: yellowish-brown; fire clouds on the rim

EXTERIOR SURFACE COLOR: yellowish-brown to reddish-brown; fire clouds on the rim and body

WALL THICKNESS (IN MM): rim, $4.9 \mathrm{~mm}$

INTERIOR SURFACE TREATMENT: none

EXTERIORSURFACETREATMENT: smoothed

HEIGHT (IN CM): 10.9

ORIFICE DIAMETER (IN CM): 8.3

DIAMETER AT BOTTOM OF RIM OR NECK (IN CM): N/A

BASE DIAMETER (IN CM) AND SHAPE OF

BASE: 5.2; circular and flat

ESTIMATED VOLUME (IN LITERS): 0.6

DECORATION (INCLUDING MOTIF AND ELEMENTS WHENAPPARENT): Plain(Figure 8)

PIGMENTUSEANDLOCATIONONVESSEL: none

TYPEANDVARIETY(IFKNOWN):Unidentified plain ware

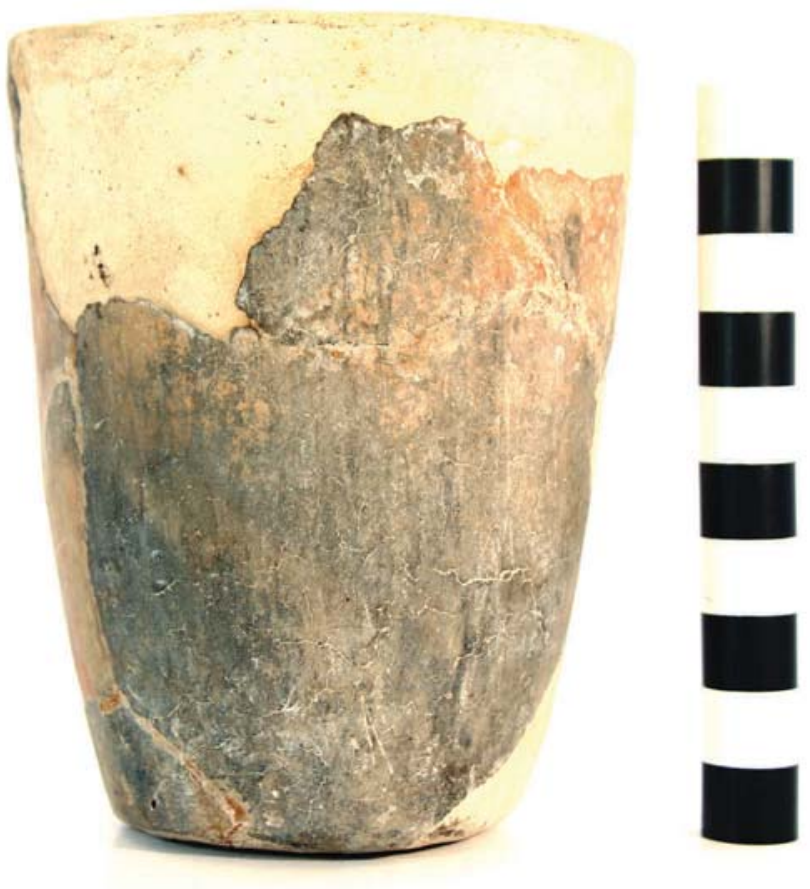

Figure 8. Plain jar or deep bowl from the Fred Yarbrough site. 
SITE NAME OR SITE NUMBER: Fred Yarbrough

VESSEL NO.: 8, 6-154-295, burned area

VESSEL FORM: Bowl

NON-PLASTICS AND PASTE: grog

RIM AND LIP FORM: Direct rim and flat lip

CORE COLOR: $\mathrm{F}$ (fired in a reducing environment and cooled in the open air)

INTERIOR SURFACE COLOR: reddish-brown to dark reddish-brown; fire clouds on the rim, body, and base EXTERIOR SURFACE COLOR: dark reddish-brown; fire clouds on the rim, body, and base

WALL THICKNESS (IN MM): rim, $5.7 \mathrm{~mm}$; body, $5.4 \mathrm{~mm}$; base, $7.6 \mathrm{~mm}$

INTERIOR SURFACE TREATMENT: smoothed

EXTERIOR SURFACE TREATMENT: smoothed

HEIGHT (IN CM): 7.6

ORIFICE DIAMETER (IN CM): 19.1

DIAMETER AT BOTTOM OF RIM OR NECK (IN CM): N/A

BASE DIAMETER (IN CM) AND SHAPE OF BASE: 8.9; circular and flat

ESTIMATED VOLUME (IN LITERS): 0.6

DECORATION (INCLUDING MOTIF AND ELEMENTS WHEN APPARENT): The rim of the vessel is decorated with at least 23 engraved pendant triangles filled with cross-hatched engraved lines. The engraved triangle elements are pendant from the vessel lip and point towards the vessel base.

PIGMENT USE AND LOCATION ON VESSEL: none

TYPE AND VARIETY (IF KNOWN): Sanders Engraved
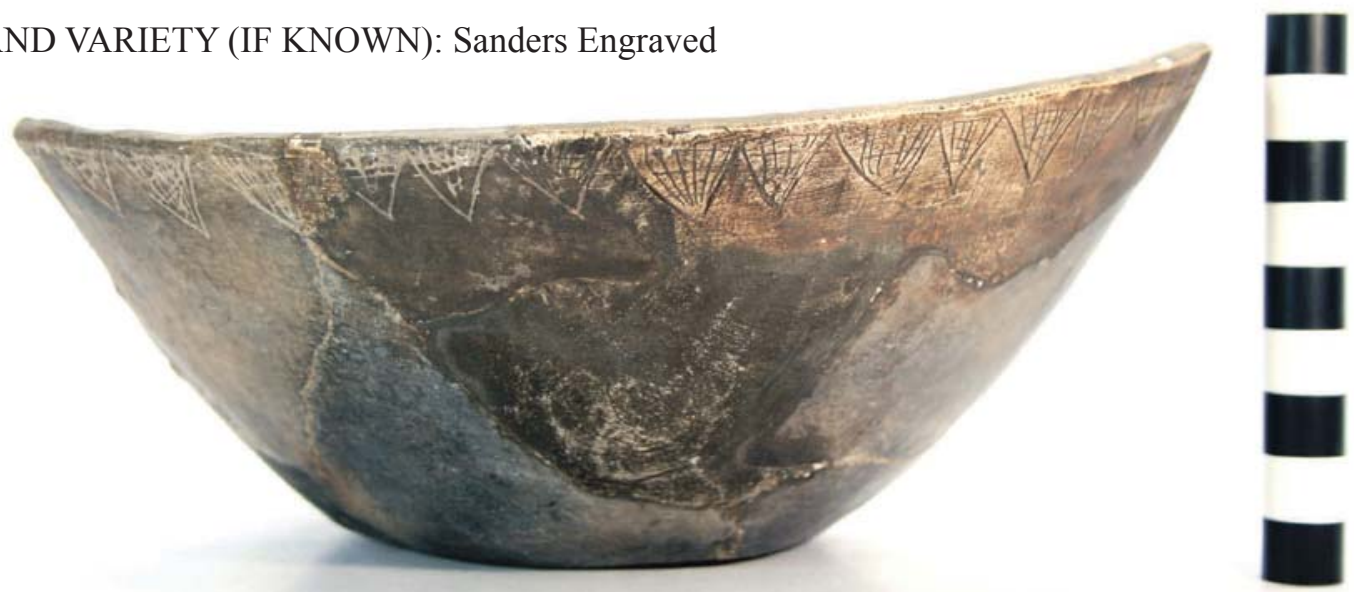

Figure 9. Sanders Engraved bowl from the Fred Yarbrough site. 
SITE NAME OR SITE NUMBER: Fred Yarbrough

VESSEL NO.: 9, 6-154-300

VESSEL FORM: Jar

NON-PLASTICS AND PASTE: grog

RIM AND LIP FORM: Direct rim and flat lip

CORE COLOR: F (fired in a reducing environment and cooled in the open air)

INTERIOR SURFACE COLOR: yellowish-brown; fire clouds on the rim and body

EXTERIOR SURFACE COLOR: dark yellowish-brown; fire clouds on the rim and body

WALL THICKNESS (IN MM): rim, $6.7 \mathrm{~mm}$

INTERIOR SURFACE TREATMENT:

none

EXTERIOR SURFACE TREATMENT: smoothed on the body

HEIGHT (IN CM): 18.4

ORIFICE DIAMETER (IN CM): 12.7

DIAMETER AT BOTTOM OF RIM OR

NECK (IN CM): 13.2

BASE DIAMETER (IN CM) AND

SHAPE OF BASE: 9.2; circular and concave

ESTIMATED VOLUME (IN LITERS):

1.4

DECORATION (INCLUDING MOTIF AND ELEMENTS WHEN APPARENT):

The vessel has cross-hatched incised lines on the rim. One area of the vessel body that has been reconstructed has overlapping brushed marks, but unreconstructed sections of the vessel have at most very faint brushing marks.

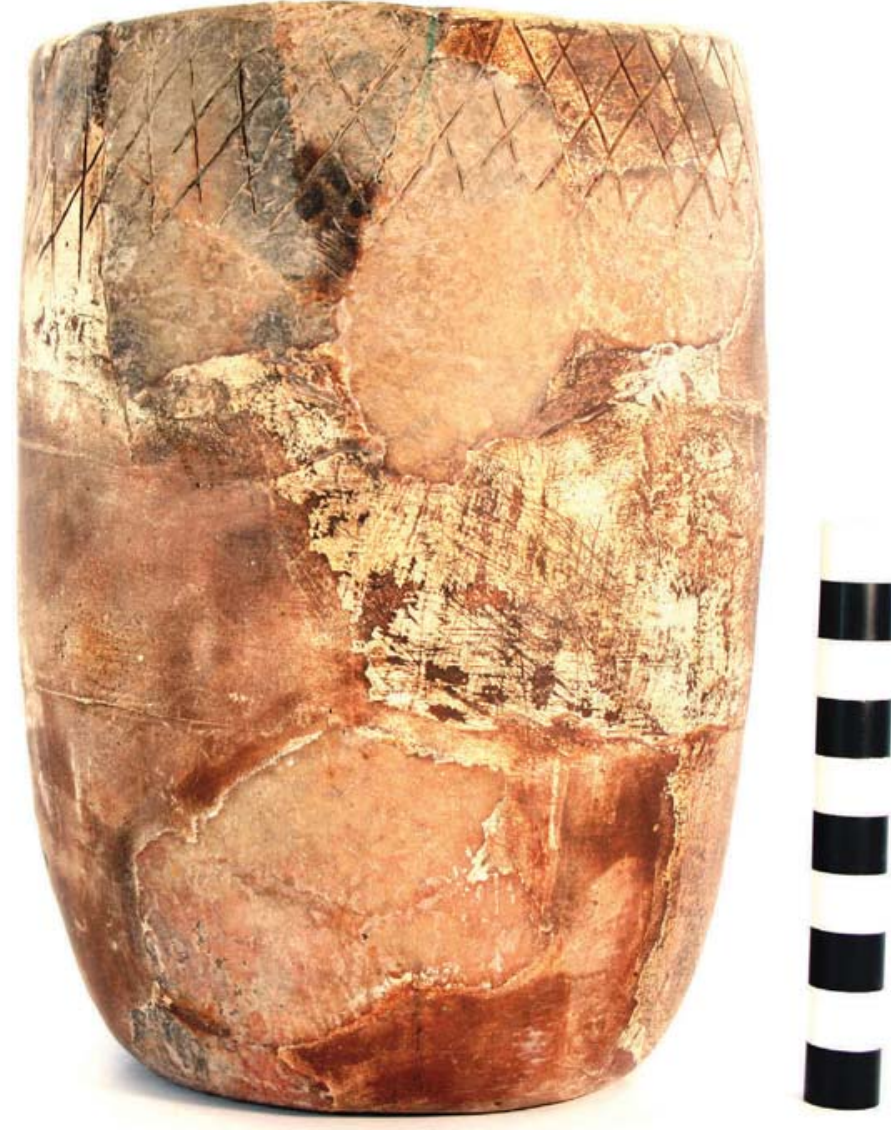

Figure 10. Canton Incised jar from the Fred Yarbrough site.

PIGMENT USE AND LOCATION ON

VESSEL: none

TYPE AND VARIETY (IF KNOWN): Canton Incised 


\section{SUMMARY AND CONCLUSIONS}

WPA excavations at the Fred Yarbrough site (41VN6) on the Sabine River in East Texas recovered nine small to medium-sized Caddo ceramic vessels or reconstructed vessel sections, none clearly from burial context. Instead, given the association of a number of the vessels with a burned area in Area B midden deposits, it is probable that these vessels were in a habitation context that was burned in prehistoric times, preserving the vessels in situ. The nine vessels include two jars, two carinated bowls, three bowls, and two bottles. One of the carinated bowls and one of the bowls are Sanders Engraved vessels, one of the bottles is a Sanders Slipped vessel, and one jar is a Canton Incised vessel. These types at the site indicate that the Area B habitation and midden deposits were deposited in the Middle Caddo period (ca. A.D. 1200-1400), in a cultural context analogous to the Sanders phase at ancestral Caddo sites in the upper Red, Sulphur, Big Cypress, and Sabine River basins in East Texas.

The vessels are tempered with grog (56 percent), grog-bone (33 percent), and grog-bone-hematite (11 percent). The vessels were fired in both oxidizing ( 22 percent) and reducing ( 78 percent) environments, but most of the latter vessels were also cooled in the open air (67 percent). Fine ware vessels (i.e., with engraved or slipped decorative elements) were commonly burnished or smoothed on one or both vessel surfaces, the one utility ware vessel (i.e., with a wet paste decoration) has been smoothed on its exterior surface, and the plain wares are either smoothed ( 80 percent) or burnished ( 20 percent) on their exterior surfaces, and smoothed (20 percent) on their interior surfaces.

\section{ACKNOWLEDGMENTS}

Bo Nelson took the photographs of the vessels from the Fred Yarbrough site. Sandra Hannum prepared Figure 1. Thanks to Marybeth Tomka for access to these vessels in the collections of the Texas Archeological Research Laboratory at The University of Texas at Austin.

\section{REFERENCES CITED}

Johnson, L., Jr.

1962 The Yarbrough and Miller Sites of Northeastern Texas, With a Preliminary Definition of the La Harpe Aspect. Bulletin of the Texas Archeological Society 32:141-284.

Perttula, T. K., M. Walters, and B. Nelson

2016 Caddo Ceramic Vessels from the T. M. Sanders Site (41LR2) on the Red River in Lamar County, Texas. Special Publication No. 41. Friends of Northeast Texas Archaeology, Austin and Pittsburg.

Wilson, A. M.

1950 Indian Life in Van Zandt County. In History of Van Zandt County, by J. Mills, pp. 66-79. Wills Point, Texas. 